\title{
Microwave Synthesized Monodisperse CdS Spheres of Different Size and Color for Solar Cell Applications
}

\author{
Carlos A. Rodríguez-Castañeda, Paola M. Moreno-Romero, \\ Claudia Martínez-Alonso, and Hailin Hu
}

Instituto de Energías Renovables, Universidad Nacional Autónoma de México, 62580 Temixco, MOR, Mexico

Correspondence should be addressed to Hailin Hu; hzh@ier.unam.mx

Received 13 January 2015; Accepted 13 March 2015

Academic Editor: Chetna Dhand

Copyright (C) 2015 Carlos A. Rodríguez-Castañeda et al. This is an open access article distributed under the Creative Commons Attribution License, which permits unrestricted use, distribution, and reproduction in any medium, provided the original work is properly cited.

\begin{abstract}
Monodisperse CdS spheres of size of 40 to $140 \mathrm{~nm}$ were obtained by microwave heating from basic solutions. It is observed that larger CdS spheres were formed at lower solution $\mathrm{pH}$ (8.4-8.8) and smaller ones at higher solution $\mathrm{pH}$ (10.8-11.3). The color of CdS products changed with solution $\mathrm{pH}$ and reaction temperature; those synthesized at lower $\mathrm{pH}$ and temperature were of greenyellow color, whereas those formed at higher $\mathrm{pH}$ and temperature were of orange-yellow color. A good photovoltage was observed in CdS:poly(3-hexylthiophene) solar cells with spherical CdS particles. This is due to the good dispersion of CdS nanoparticles in P3HT solution that led to a large interface area between the organic and inorganic semiconductors. Higher photocurrent density was obtained in green-yellow CdS particles of lower defect density. The efficient microwave chemistry accelerated the hydrolysis of thiourea in $\mathrm{pH}$ lower than 9 and produced monodisperse spherical CdS nanoparticles suitable for solar cell applications.
\end{abstract}

\section{Introduction}

The increasing social conscience on the use of clean and renewable energy resources motivates the search on new materials, processes, or technologies for clean energy conversion systems. For solar photovoltaics, in particular, the research activities on low cost organic or hybrid (organic-inorganic) solar cells are very intensive. The so-called hybrid heterojunction solar cells contain photoactive layers consisting of an inorganic semiconductor as electron conductor and an organic one as hole conductor. The inorganic semiconductors could be $\mathrm{PbS}, \mathrm{Si}, \mathrm{CdTe}, \mathrm{CdSe}, \mathrm{CdS}, \mathrm{TiO}_{2}, \mathrm{ZnO}$, and so forth, and the organic semiconductors could be poly(3-hexylthiophene-2,5-diyl) (P3HT), poly(2-methoxy5-(20-ethylhexyloxy)-1,4-phenylene vinylene) (MEH-PPV), poly(2,6-(4,4-bis-(2-ethylhexyl)-4H-cyclopenta(2,1-b;3,4-b)dithio-phene)-alt-4,7-(2,1,3-benzo-thiadiazole)) (РСРDTBT), poly[[4,8-bis[(2-ethylhexyl)oxy] benzo [1,2-b:4,5-b0] dithiophene-2,6-diyl][3-fluoro-2-[(2-ethylhexyl)carbonyl] thieno[3, 4-b]thiophenediyl]] (PTB7), and so forth. Review articles about hybrid solar cells can be found in literature [1-3].
Among the inorganic electron conductors, cadmium sulfide (CdS) was one of the most studied [4-6]; the energy conversion efficiency of the solar cells achieved $4.1 \%$ by using CdS quantum dots bound onto crystalline P3HT nanowires through solvent-assisted grafting and ligand exchange [7]. In literature, the CdS nanocrystals with size smaller than $10 \mathrm{~nm}$ were mostly synthesized through solution via using encapsulation agents, trioctylphosphine oxide (TOPO), for example, to avoid the agglomeration of the crystals [8]; without any encapsulation agent, the obtained CdS particles were of micron size and showed hydrophobic characteristic [9]. Since the encapsulation agents were electrically insulated, their presence in the active layers increases the series resistance and reduces the energy conversion efficiency of the resulting solar cells. The synthesis of larger monodisperse CdS spheres of 0.25 to $20 \mu \mathrm{m}$ without encapsulation agent had been reported by using colloidal method in acidic solutions [10-12], although the optical and electrical properties of the obtained CdS products had not been analyzed in those works.

Microwave heating is also an effective and homogeneous process that can be used for synthesis of inorganic 
nanoparticles. Microwave radiations can heat any material containing mobile charge such as polar molecules or ions in solutions or solids. For example, spherical monodisperse nanomaterials of organically passivated binary and ternary III-V(InGaP, InP) and II-VI (CdSe) materials were synthesized with microwave synthetic methodology [13]. The organic passivation of the nanomaterials was through the use of the strong microwave absorber TOPO that led to the formation of spherical nanocrystals of 2-6 nm, depending on the reaction temperature and radiation power. On the other hand, highly monodisperse submicrometer CdS colloidal spheres with a controllable and tunable size (between 80 and $500 \mathrm{~nm}$ ) have been synthesized through a solvothermal technique with salts of cadmium $\left(\mathrm{Cd}\left(\mathrm{NO}_{3}\right)_{2} \cdot 3 \mathrm{H}_{2} \mathrm{O}\right)$, thiourea (TU), and polyvinylpyrrolidone (PVP) in ethylene glycol [14]. The mixture was sealed in a $50 \mathrm{~mL}$ PTFE-lined stainlesssteel autoclave and was heated at $140^{\circ} \mathrm{C}$ for $8 \mathrm{~h}$ to $24 \mathrm{~h}$, which was quite long compared to microwave synthesis method (usually less than $30 \mathrm{~min}$ ). However, the presence of about $8 \mathrm{wt} \%$ PVP as residues in the product was detected even after the sample had been thoroughly washed.

Either TOPO or PVP helps to form monodisperse spherical CdS of size from nanometers to submicrons. The synthesis of CdS nanoparticles without organic dispersers has been a challenge for solar cell applications. In a previous work, cadmium salt, sodium citrate, $\mathrm{pH}$ adjuster $(\mathrm{KOH})$, and two different sources of sulfur, thioacetamide (TA) or TU, were used to synthesize $\mathrm{CdS}$ in a microwave oven with basic solutions [15]. It reported that the $\mathrm{CdS}$ products from TA recipe were much more crystalline and showed morphology of hexagonal particles with random distribution of particle size. Under the same reaction conditions, however, the use of TU led to the formation of hydrophobic monodisperse spherical $\mathrm{CdS}$ particles of about $100 \mathrm{~nm}$. In this work, it is demonstrated that monodisperse spherical CdS nanoparticles with diameters from 40 to $140 \mathrm{~nm}$ could be obtained through a careful control of solution $\mathrm{pH}$, reaction temperature, and time during the microwave assisted heating. The homogeneous heating and enhanced reaction rates given by microwave chemistry [13] enabled the formation of monodisperse CdS spheres of different particle and crystal sizes. The effect of synthesis conditions of $\mathrm{CdS}$ products on the photovoltaic performance of CdS-P3HT hybrid solar cells was also analyzed. Microwave heating was a simple and efficient method to obtain monodisperse inorganic semiconductor nanoparticles for solar cell applications.

\section{Experimental}

CdS nanoparticles were synthesized in a microwave oven (Anton Paar Synthos 3000). The solution was made of $19 \mathrm{~mL}$ of $0.03 \mathrm{M} \mathrm{CdCl}_{2}$ (Reasol), $9 \mathrm{~mL}$ of $0.1 \mathrm{mM}$ sodium citrate ( $\left.\mathrm{HOC}(\mathrm{COONa})\left(\mathrm{CH}_{2} \mathrm{COONa}\right)_{2}\right)$ (Fermont, 99.9\%), 1-3 mL of $0.1 \mathrm{MKOH}$ (J. T. Baker $88 \%$ ) to keep the $\mathrm{pH}$ value of the solution between 8.4 and $11.3,19 \mathrm{~mL}$ of $0.3 \mathrm{MTU}$ $\left(\mathrm{NH}_{2} \mathrm{CSNH}_{2}\right)$ (Fermont $99.3 \%$ ), and $1.5 \mathrm{~mL}$ of deionized water. The total reaction solution in a reactor tube was $50 \mathrm{~mL}$. The reaction temperature was set at 100 or $150^{\circ} \mathrm{C}$, the reaction time for 10 or $30 \mathrm{~min}$, and the power of the microwave oven at
$600 \mathrm{~W}$. The initial reaction pressure was $0.8-2$ bars and ended up to 60 bars. The obtained CdS suspension was centrifuged, decanted, rinsed with methanol, centrifuged for the second time, decanted again, and dried at room temperature for about $48 \mathrm{~h}$. No further washing or thermal treatment was made on the dried CdS products.

X-ray diffraction (XRD) patterns of CdS powders were recorded in a Rigaku Ultima IV X-ray diffractometer $(\mathrm{CuK}$ radiation $\lambda=0.154 \mathrm{~nm}$ ). Scanning electron microscope (SEM) analysis was performed in a Hitachi FE-5500. The size distribution of CdS nanoparticles in an area of $3 \mu \mathrm{m} \times$ $3 \mu \mathrm{m}$ was counted with the free software IMAGEJ64. Photoluminescence spectra of CdS powders, dispersed in water, were taken in a Perkin-Elmer Fluorimeter LS55 with $370 \mathrm{~nm}$ as excitation wavelength for emission spectra and a filter of $430 \mathrm{~nm}$ to eliminate the second harmonic signals. The concentration of the powder in water was about 0.75 to $1.5 \mathrm{mg} / \mathrm{mL}$ to maintain the particles separated in the solution (appearance of $450 \mathrm{~nm}$ emission band; see the text in the next section). Fourier transform infrared (FT-IR) spectra of $\mathrm{CdS}$ powders in $\mathrm{KBr}$ pellets were recorded in a Spectrum GX of Perkin-Elmer. Thermogravimetric analysis (TGA) was carried out in a TGA Q500 of TA Instruments in a temperature range of 20 to $400^{\circ} \mathrm{C}$ with a heating rate of $10^{\circ} \mathrm{C} / \mathrm{min}$ under nitrogen ambient.

For solar cell preparation, thin films of cadmium sulfide (CdS-f), of thickness of about $50 \mathrm{~nm}$, were deposited by chemical bath deposition on transparent conductive glass substrates (indium tin oxide, ITO, coated glass with sheet resistance of $15 \Omega$ per square, Lumtec) with the same process as described previously [16]. CdS-f acts as a hole blocking layer in hybrid solar cells. The active layers were formed by CdS powder with poly(3-hexylthiophene) (P3HT, Aldrich regioregular, 97\%). Dried CdS powder was blended with P3HT solution in 1,2-dichlorobenzene (DCB). The weight ratio between inorganic nanoparticles and conducting polymer, CdS:P3HT, was chosen as $1: 1$ or $3: 1$. The mixed solution was spin coated on the CdS-f, dried at $70-80^{\circ} \mathrm{C}$, and annealed at $150^{\circ} \mathrm{C}$ for $10 \mathrm{~min}$. Carbon paint (CP) solution was spread first on the surface of active layers and dried in air. Then gold contacts of about $40 \mathrm{~nm}$ of thickness were deposited by thermal evaporation on top of CP. The use of CP was to improve the ohmic contact between $\mathrm{P} 3 \mathrm{HT}$ and Au and avoid the gold atom diffusion towards the active layer [17]. The final structure of the cells was ITO/CdS-f/CdS-P3HT/CP/Au, and the whole devices were annealed in air at $110^{\circ} \mathrm{C}$ for $10 \mathrm{~min}$ to improve the junction between the metal contact and the active layer. Current-voltage $(I-V)$ curves of solar cells were taken under illumination of one Sun with a solar simulator (Oriel) in air under ambient conditions. The intensity of the xenon lamp was adjusted to $100 \mathrm{~mW} / \mathrm{cm}^{2}$.

\section{Results and Discussion}

3.1. Monodisperse Spherical CdS Particles. Spherical particles with relatively narrow distributions have been observed in microwave synthesized $\mathrm{CdS}$ products at $100^{\circ} \mathrm{C}$ or $150^{\circ} \mathrm{C}$ for 10 or 30 min from solutions of $\mathrm{pH} 8.5$ to 10.8 (Figure 1). The size of the particles varied from $52 \mathrm{~nm}$ to $137 \mathrm{~nm}$ and 


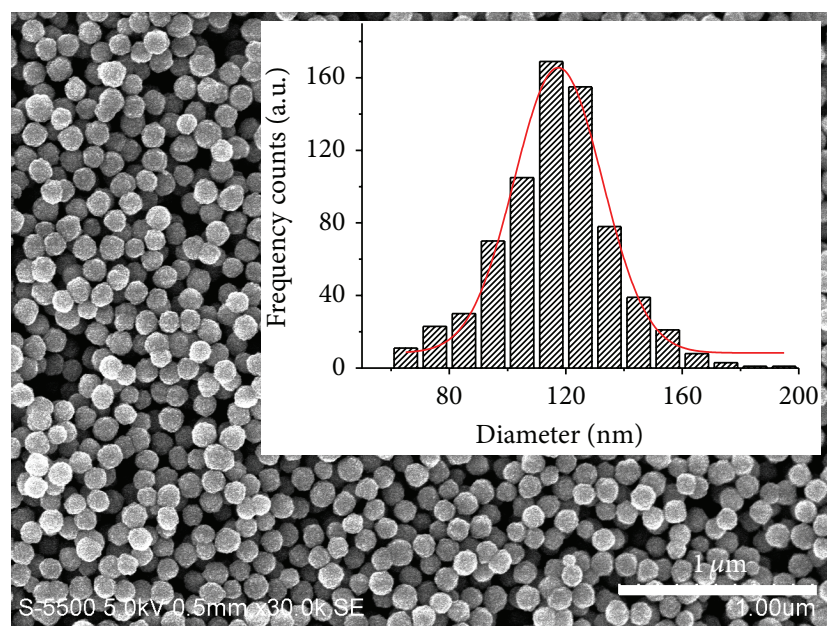

(a) $\mathrm{pH} 8.5,100^{\circ} \mathrm{C}, 10 \mathrm{~min}, 117.42 \mathrm{~nm} \pm 17.84 \mathrm{~nm}$

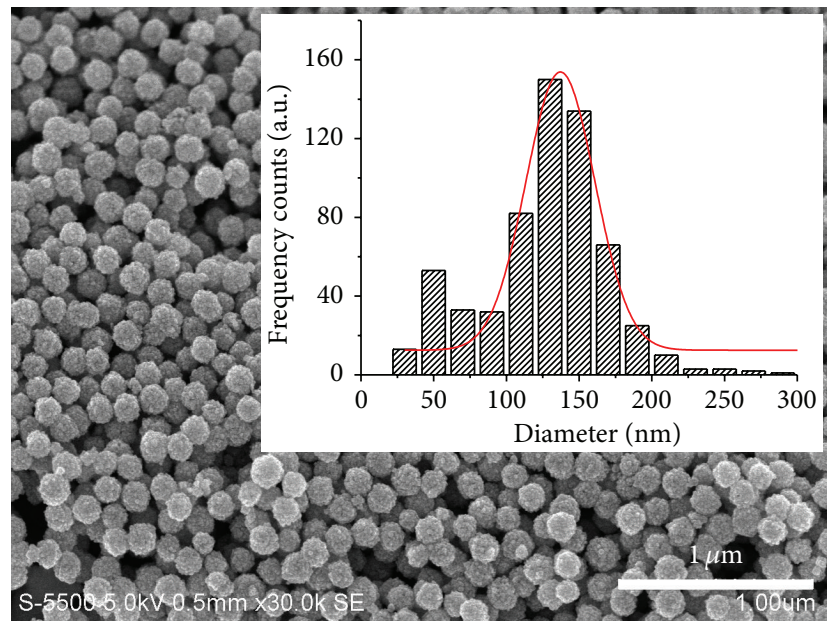

(c) $\mathrm{pH} 8.4,150^{\circ} \mathrm{C}, 10 \mathrm{~min}, 137.14 \mathrm{~nm} \pm 27.92 \mathrm{~nm}$

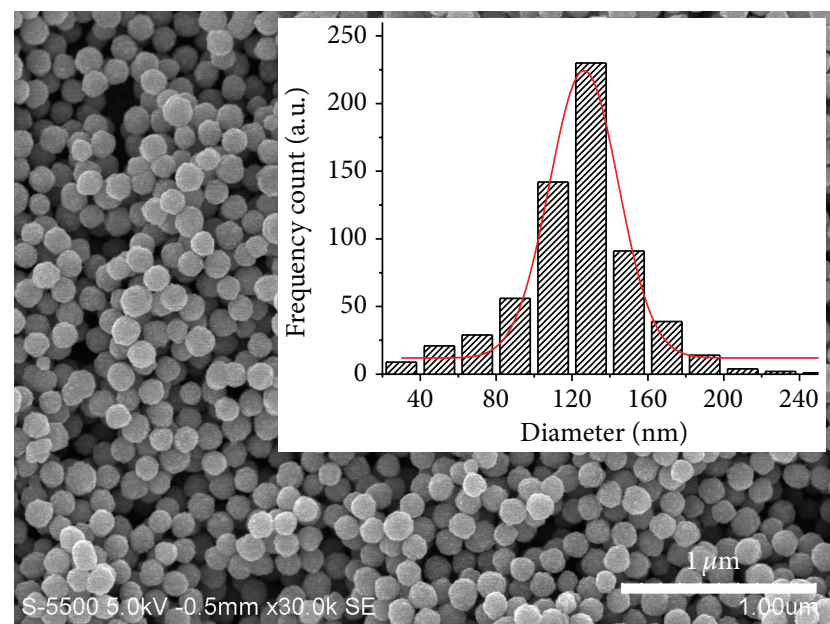

(b) $\mathrm{pH} 8.5,100^{\circ} \mathrm{C}, 30 \mathrm{~min}, 126.32 \mathrm{~nm} \pm 21.37 \mathrm{~nm}$

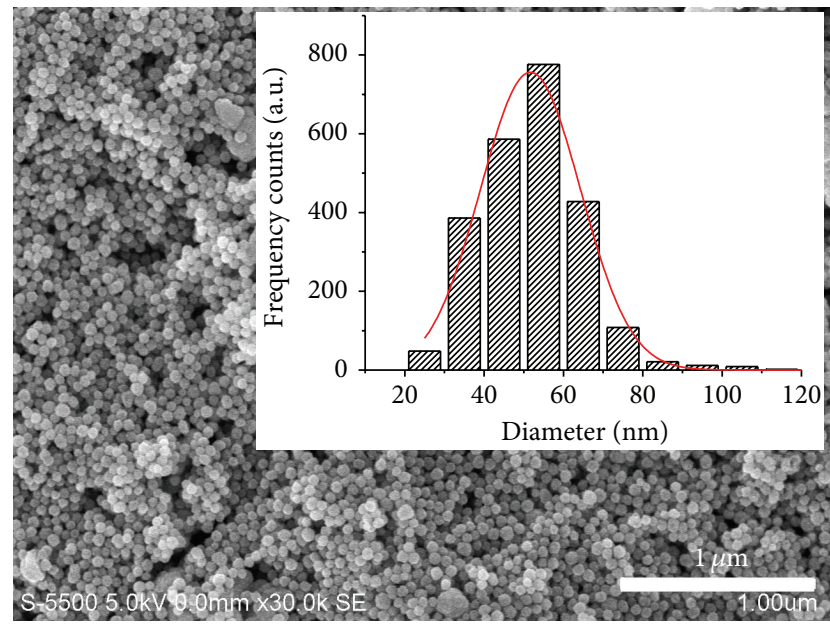

(d) $\mathrm{pH} 10.8,100^{\circ} \mathrm{C}, 30 \mathrm{~min}, 51.68 \mathrm{~nm} \pm 14.85 \mathrm{~nm}$

FIGURE 1: SEM micrographs of monodisperse CdS nanoparticles synthesized by microwave heating at (a) $100^{\circ} \mathrm{C}$ for $10 \mathrm{~min}$ with solution of $\mathrm{pH} 8.5$, (b) $100^{\circ} \mathrm{C}$ for $30 \mathrm{~min}$ with solution of $\mathrm{pH} 8.5$, (c) $150^{\circ} \mathrm{C}$ for $10 \mathrm{~min}$ with solution of $\mathrm{pH} 8.4$, and (d) $100^{\circ} \mathrm{C}$ for 30 min with solution of $\mathrm{pH} 10.8$.

was a function of the initial solution $\mathrm{pH}$ (Figure 1(b) versus Figure 1(d)), the reaction temperature (Figure 1(a) versus Figure 1(c)), and time (Figure 1(a) versus Figure 1(b)). The effect of the experimental conditions on the formation of monodisperse CdS nanoparticles will be discussed as follows.

3.1.1. Effect of $p H$. The formation of monodisperse spherical CdS particles was faster in solutions of lower $\mathrm{pH}$. For example, at reaction temperature $\left(100^{\circ} \mathrm{C}\right), \mathrm{CdS}$ spheres of about $117 \mathrm{~nm}$ were formed during the first $10 \mathrm{~min}$ of reaction when the solution $\mathrm{pH}$ was at 8.4 to 8.8 (Figure 1(a)). However, at the same reaction temperature it would take about $30 \mathrm{~min}$ to form smaller particles (about $51 \mathrm{~nm}$ ) from solutions of $\mathrm{pH}$ values between 10.8 and 11.3 (Figure 1(d)). Figure 2 shows the dependence of CdS particle size $(y)$ as a function of the solution $\mathrm{pH}$ value ( $x$, in an interval of 8.5 to 11.3 ) for those CdS products synthesized at $100^{\circ} \mathrm{C}$ for $30 \mathrm{~min}$. The experimental data were fitted with an exponential decay: $y=43.11+94.70 \exp (-(x-8.40) / 0.69)$. Under the same synthesis temperature for the same period of time, lower $\mathrm{pH}$ produced larger spherical CdS particles.

3.1.2. Effect of Reaction Time. At low $\mathrm{pH}$ region (8.4 to 8.8), monodisperse CdS nanoparticles were formed independent of the reaction temperature and time, as observed in Figures 1(a), 1(b), and 1(c). Longer reaction time led to larger particle size. Figures 3(a) and 3(b) exhibit SEM images with larger magnification of the same samples in Figures 1(a) and 1(b): $\mathrm{CdS}$ products synthesized from solutions of $\mathrm{pH} 8.5$ at $100^{\circ} \mathrm{C}$ for $10 \mathrm{~min}$ (Figure 3(a)) and $30 \mathrm{~min}$ (Figure 3(b)). The average particle size was $117 \mathrm{~nm}$ after $10 \mathrm{~min}$ of reaction, and it became about $126 \mathrm{~nm}$ after $30 \mathrm{~min}$ of reaction. The increase of the diameter of the particles was about $8 \%$ in the additional 20 min of reaction.

However, at high pH region (10.8 to 11.3), the formation of spherical particles took longer time and the particle size 


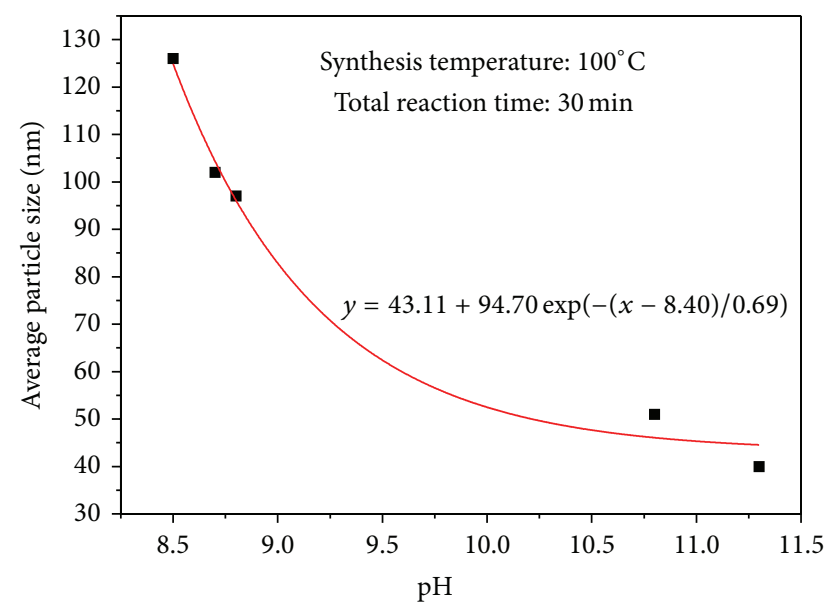

FIGURE 2: Correlation of the average CdS particle size and the $\mathrm{pH}$ of the initial solution for those $\mathrm{CdS}$ products synthesized at $100^{\circ} \mathrm{C}$ for $30 \mathrm{~min}$ (black squares). The data were fitted with single exponential decay (red solid line).

was smaller in comparison with those synthesized at lower $\mathrm{pH}$. Figures 3(c) and 3(d) show the SEM images of two CdS products synthesized at $100^{\circ} \mathrm{C}$ and a high $\mathrm{pH}$ value (11.2) with the difference on the reaction time. It is observed that the interval of $10 \mathrm{~min}$ was not sufficient to form separated spherical CdS particles (Figure 3(c)), and after $30 \mathrm{~min}$ of reaction the previous long chains of CdS were separated into individual CdS particles with an average size of about $40 \mathrm{~nm}$ (Figure 3(d)). If the reaction temperature was at $150^{\circ} \mathrm{C}$, the very small CdS particles were agglomerated into large clusters and after $10 \mathrm{~min}$ of reaction no separated spheres could be formed (Figure 3(e)).

3.1.3. Effect of Reaction Temperature. The range of reaction temperature for CdS synthesis by microwave heating had been chosen originally between 50 and $150^{\circ} \mathrm{C}$. But the reaction kinetics was so slow at $50^{\circ} \mathrm{C}$ that it took $60 \mathrm{~min}$ to obtain about $10 \mathrm{mg}$ of the CdS product, which was not sufficient to prepare one solar cell. Therefore, it decided to choose $100^{\circ} \mathrm{C}$ or $150^{\circ} \mathrm{C}$ as the reaction temperature. The CdS products synthesized at these two temperatures for $10 \mathrm{~min}$ and at the same solution $\mathrm{pH}$ were compared to analyze the effect of the reaction temperature on the CdS crystal or particle characteristics.

As showed in Figures 1(a) and 1(c), larger CdS spheres were obtained at higher reaction temperature when the solution $\mathrm{pH}$ was low (8.4-8.8). In both cases, spherical particles with diameters of about $100 \mathrm{~nm}$ were observed. By making a statistic counting in areas of more than $3 \mu \mathrm{m} \times$ $3 \mu \mathrm{m}$, it is found that the average size of CdS synthesized at $100^{\circ} \mathrm{C}$ for $10 \mathrm{~min}$ was $117.42 \pm 17.84 \mathrm{~nm}$ (Figure $1(\mathrm{a})$ ), whereas the average size of $\mathrm{CdS}$ synthesized at $150^{\circ} \mathrm{C}$ for $10 \mathrm{~min}$ was equal to $137.14 \pm 27.92$ (Figure $1(\mathrm{c})$ ). This suggests that the higher the reaction temperature, the larger the average CdS particle size. As for higher solution $\mathrm{pH}$ values (10.8-11.3), no spherical CdS nanoparticles were formed, for synthesis time interval of $10 \mathrm{~min}$, either at $100^{\circ} \mathrm{C}$ (Figure 3(c)) or at $150^{\circ} \mathrm{C}$ (Figure 3(e)). This concludes that the main factor that controls the formation of spherical CdS particles was the solution $\mathrm{pH}$ value; the effect of temperature was to increase the particle size (lower $\mathrm{pH}$ ) or change the surface morphology of the CdS products (higher $\mathrm{pH}$ ), as will be discussed in the next section.

In a conventional solution precipitation process, the hydrolysis of thiourea at 60 to $80^{\circ} \mathrm{C}$ requires a solution $\mathrm{pH}$ higher than 10; the precipitation of CdS powder or formation of CdS thin film was kinetically too slow as the $\mathrm{pH}$ of the solution was lower than 9. The CdS products obtained in this work confirmed that microwave chemistry enhances hydrolysis of thiourea at $\mathrm{pH}$ lower than 9 either by overcoming local intermediates (ions, solvents, etc.) which act as traps along the reaction trajectory or by increasing the microscopic temperature of the reaction [13]. The combination of an adequate kinetics of reaction at lower $\mathrm{pH}$ and the homogeneous interaction of microwave radiation with solvent and polar molecules/ions made the formation of monodisperse spherical CdS nanoparticles at low reaction temperature in a short period of time possible.

3.2. CdS Crystal Size and Emission Bands. All the CdS particles observed in previous SEM images contain smaller grains or crystals. Figures 4(a) and 4(b) exhibit the SEM images with larger magnification of the same samples showed in Figures 1(a) and 1(c), respectively, synthesized at 100 and $150^{\circ} \mathrm{C}$ for $10 \mathrm{~min}$ from solutions of $\mathrm{pH}$ 8.4-8.5. They indicate that the size of grains or crystals inside the particles depends on the reaction temperature, and higher reaction temperature induced larger size of grains or crystals. XRD patterns of the two CdS products in Figure 4 were exhibited in Figure 5(a). With the maximum peaks located at $2 \theta$ around $24.8^{\circ}, 26.5^{\circ}$, $28.2^{\circ}, 44.0^{\circ}, 47.8^{\circ}$, and $52.1^{\circ}$, the CdS products obtained by microwave heating were crystalline of hexagonal Greenockite CdS structure (JCPDS 08-0006). Using the Scherer equation the average crystal size was estimated by choosing the diffraction peak at $44^{\circ}$, and it was found to be $9.2 \mathrm{~nm}$ for $\mathrm{CdS}$ synthesized at $100^{\circ} \mathrm{C}$ and $10.4 \mathrm{~nm}$ for that synthesized at $150^{\circ} \mathrm{C}$ (SEM images in Figures 4(a) and 4(b), resp.).

The same crystalline structure was also observed in the CdS products obtained from high solution $\mathrm{pH}$ (11.0 to 11.3) even as they did not have a spherical morphology (SEM images in Figures 3(c) and 3(e)). In these cases the XRD patterns (Figure 5(b)) demonstrate that the crystal size was $10.4 \mathrm{~nm}$ for CdS synthesized at $150^{\circ} \mathrm{C}$ for $10 \mathrm{~min}$ and $10.0 \mathrm{~nm}$ for those synthesized at $100^{\circ} \mathrm{C}$ for $10 \mathrm{~min}$. On the other hand, comparing the XRD patterns in Figures 5(a) and 5(b), it is concluded that the solution $\mathrm{pH}$ also influences the CdS crystal size. The CdS products synthesized at lower temperature $\left(100^{\circ} \mathrm{C}\right.$ for $\left.10 \mathrm{~min}\right)$ from solutions of $\mathrm{pH} 8.5$ and 11.0 indicated that lower $\mathrm{pH}$ sample had smaller crystal size $(9.2 \mathrm{~nm})$, and the higher $\mathrm{pH}$ sample had larger crystal size $(9.5 \mathrm{~nm})$. At the same time, lower $\mathrm{pH}$ sample (Figure 1(b)) had larger spherical particle size $(126 \mathrm{~nm})$, and the higher $\mathrm{pH}$ one (Figure 1(d)) showed the smaller particle size $(52 \mathrm{~nm})$. Namely, under the same reaction conditions, high solution $\mathrm{pH}$ enlarged the CdS crystal size but reduced the diameter of the spherical CdS particles. Finally, it is observed that 


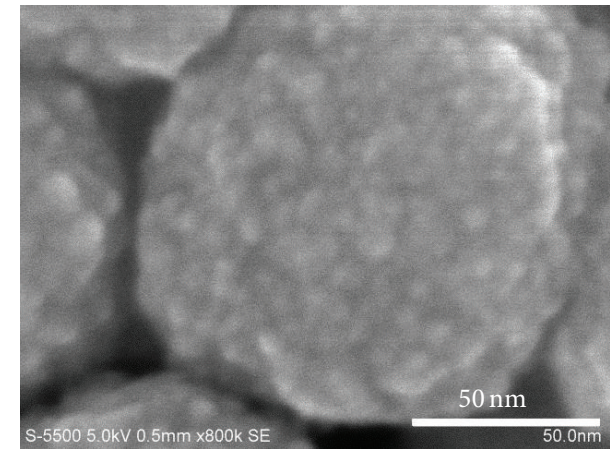

(a)

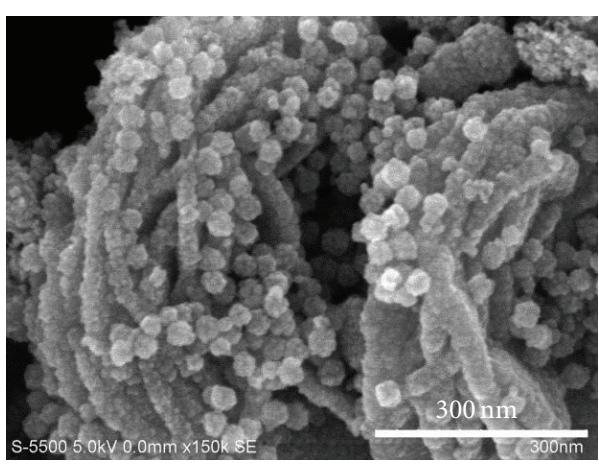

(c)

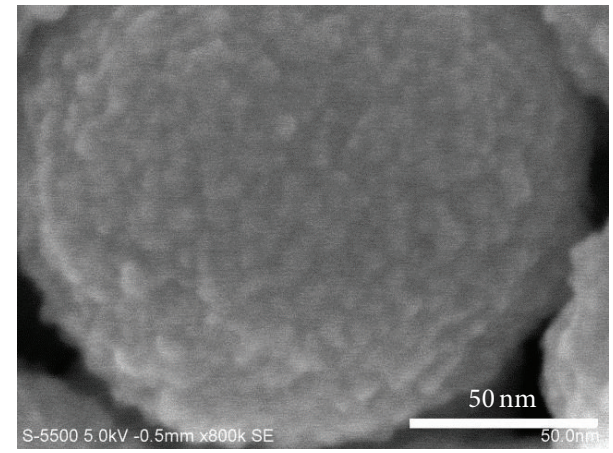

(b)

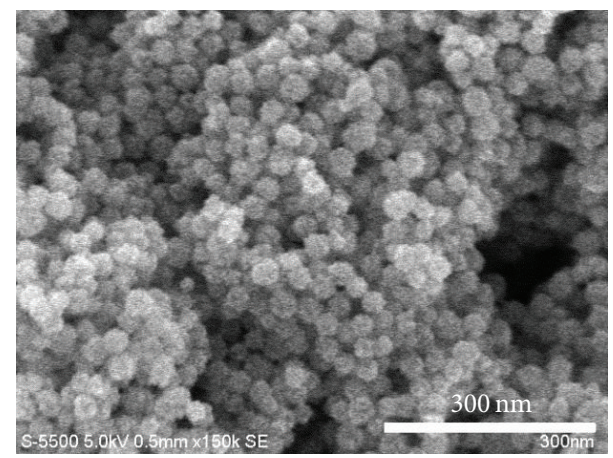

(d)

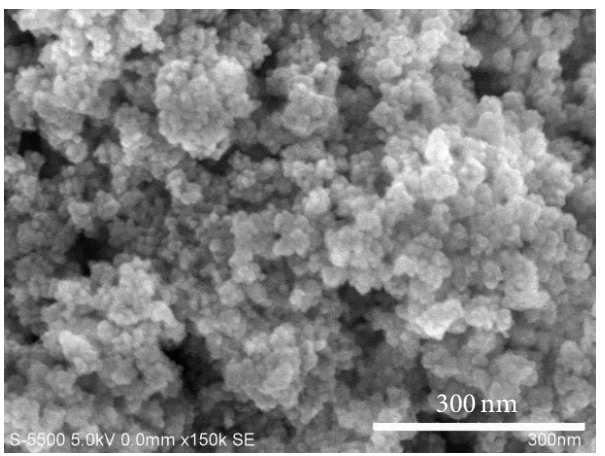

(e)

FIGURE 3: SEM images of CdS products synthesized in solutions with the initial $\mathrm{pH} 8.5$ at $100^{\circ} \mathrm{C}$ for (a) $10 \mathrm{~min}$ and (b) $30 \mathrm{~min}$. SEM images of $\mathrm{CdS}$ nanoparticles synthesized with the initial solution of $\mathrm{pH} 11.2 \pm 0.1$ (c) at $100^{\circ} \mathrm{C}$ for $10 \mathrm{~min}$, (d) at $100^{\circ} \mathrm{C}$ for $30 \mathrm{~min}$, and (e) at $150^{\circ} \mathrm{C}$ for $10 \mathrm{~min}$.

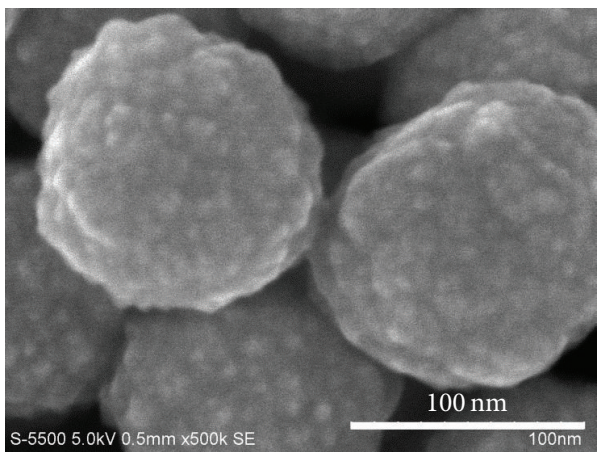

(a)

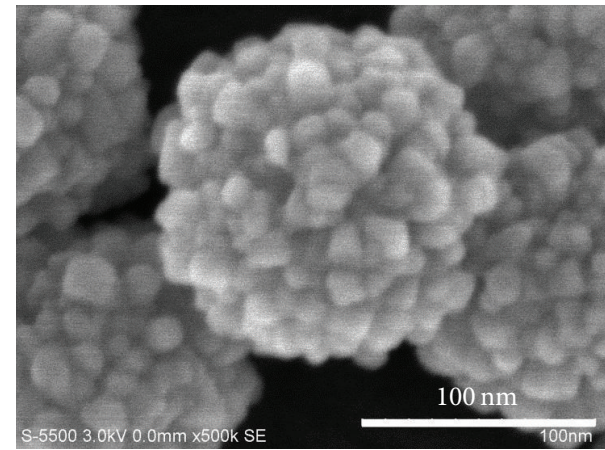

(b)

FIgURE 4: SEM images of CdS nanoparticles synthesized with pH $8.5 \pm 0.1$ of the initial solutions at (a) $100^{\circ} \mathrm{C}$ and (b) $150^{\circ} \mathrm{C}$ for $10 \mathrm{~min}$. 


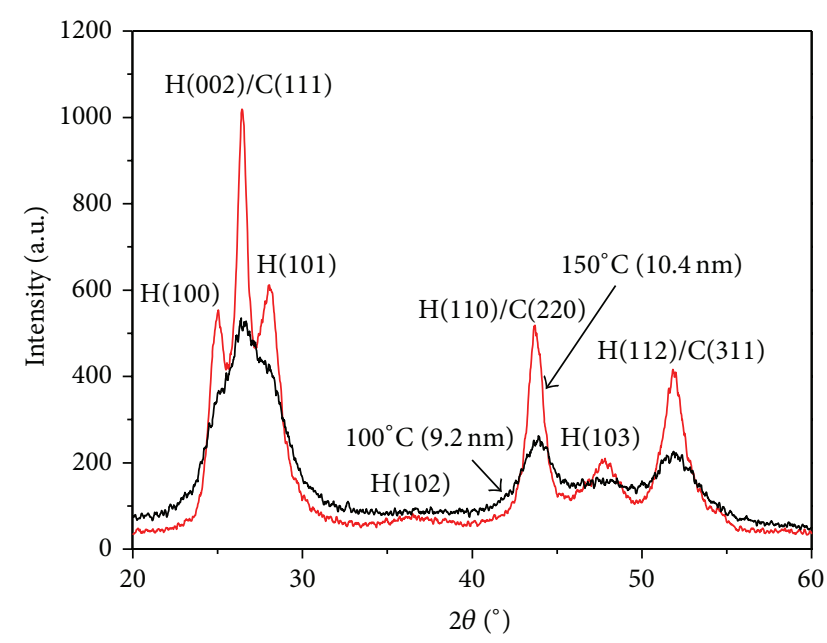

(a) $\mathrm{pH} 8.4-8.5$

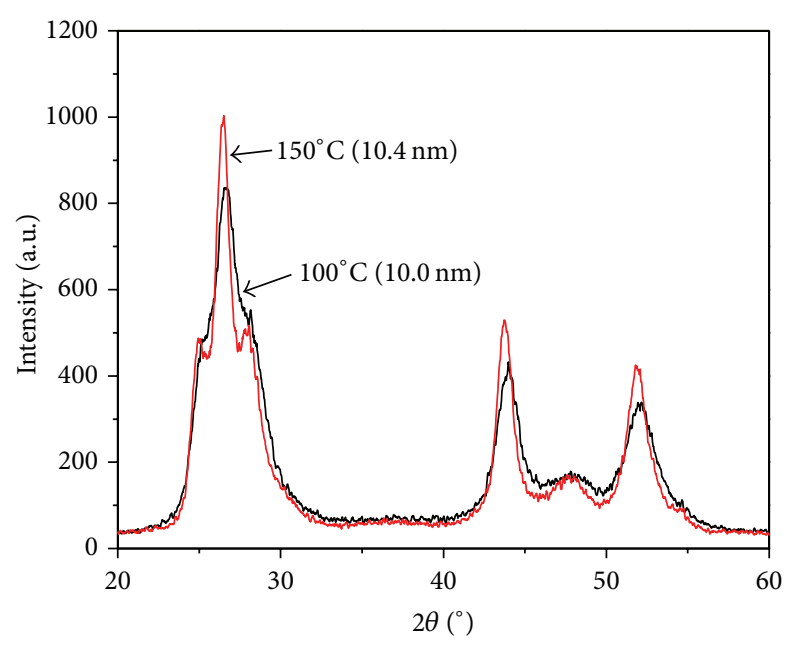

(b) $\mathrm{pH} 11.0-11.3$

FIGURE 5: XRD patterns of CdS products synthesized (a) at 100 and $150^{\circ} \mathrm{C}$ for $10 \mathrm{~min}$ from solutions of $\mathrm{pH} 8.4-8.5$ (Figures 5(a) and 5(b), resp.), (b) at $100^{\circ} \mathrm{C}$ and $150^{\circ} \mathrm{C}$ for $10 \mathrm{~min}$ from solutions of $\mathrm{pH} 11.0-11.3$ (Figures 4(a) and 4(c), resp.).

the reaction time did not affect the crystal size of the CdS products (not showed here), although it did increase the spherical particle size, as mentioned before.

Formation of larger CdS crystallites at alkaline solutions obeys the chemical reaction mechanism of CdS solution precipitation with thiourea [18-20]. The hydrolysis of thiourea requires higher concentration of hydroxide $\left(\mathrm{OH}^{-}\right)$and the formation of $\mathrm{CdS}$ was favored at $\mathrm{pH} 11$ during the conventional solution precipitation. Larger nucleation-growth rate of CdS crystals at higher solution $\mathrm{pH}$ reduces the probability of CdS agglomeration, since the rapid crystal nucleationgrowth process would overcome that of the crystal agglomeration on the existing particles. Therefore, when the solution $\mathrm{pH}$ was higher, larger amount of smaller particles would be formed, as can be seen in the SEM images of the CdS samples obtained at higher $\mathrm{pH}$ (Figures 3(c)-3(e)). Actually, the yield of the CdS product from $\mathrm{pH} 10.8$ solution was $158.9 \mathrm{mg}$, much higher than that from the $\mathrm{pH} 8.8$ one: $90.4 \mathrm{mg}$, when the reaction temperature was at $100^{\circ} \mathrm{C}$ and the interval of reaction time was $30 \mathrm{~min}$ for a total solution volume of $100 \mathrm{~mL}$.

At the same time, optical properties of CdS products also showed the dependence on the $\mathrm{pH}$ value of the synthesis solution. It is observed that two different colors were observed in the CdS products under white light reflection: greenyellow color for those synthesized at $100^{\circ} \mathrm{C}$ (or lower) with the solution $\mathrm{pH}$ smaller than 9.4, or orange-yellow color for the rest of the synthesis conditions. The reaction time did not affect the color of CdS products if they were synthesized at the same temperature for the same solution $\mathrm{pH}$. The different color of the CdS products should come from the different optical properties of the materials, which in turn should be related to the size and/or surface defects of the crystals inside the CdS particles.

Photoluminescence (PL) spectra of CdS particles dispersed in water describe the light emissions occurring when the photoexcited electrons went from excited states back to ground states after the incidence of monochromatic light. Since the intensity of the xenon lamp was not strong, the incident light on the CdS nanoparticles would be mostly absorbed by the atoms at the outside layers of those nanoparticles and the resulting emission spectra should indicate the available energy states of the species at the exterior layers of CdS particles. Figure 6 exhibits the PL spectra after the $370 \mathrm{~nm}$ wavelength excitation of the same $4 \mathrm{CdS}$ samples in Figure 5. All the PL spectra had been deconvoluted into four or five individual bands, choosing each shoulder in the original spectra as the center of an individual band. It was observed that the emission band at around 440$450 \mathrm{~nm}$ appeared as the concentration of CdS powder in water solution was dilute, and it vanished as the concentration of CdS powder was high [20]. That band should be associated with the emission of soluble or molecular CdS product. The second band at $492-495 \mathrm{~nm}(2.51 \mathrm{eV})$ could be assigned to the band gap transition (edge to edge) of CdS nanoparticles. The third one at $522-529 \mathrm{~nm}(2.36 \mathrm{eV})$ should be associated with the band gap transition of bulk CdS [21, 22]. The emission band at 538 to $550 \mathrm{~nm}(2.28 \mathrm{eV})$ should be electron transition from energy levels of surface states or bulk defects to the valence band of CdS.

The color of CdS samples under white light reflection and their PL spectra after UV light excitation are always related. The sample of Figure 6(a) was the only one among the four in Figure 6 that showed the green-yellow color and was the only one that had the maximum emission peak at about $490 \mathrm{~nm}$ with a narrow band. The rest of them had orangeyellow color and the maximum emission peak at around $525 \mathrm{~nm}$ with a wide band. Furthermore, the PL intensity of the green-yellow sample was almost 4 times that of the orangeyellow ones. Pure CdS has a band gap value lower than $525 \mathrm{~nm}$ and is of lemon green color (or green-yellow). Orange color of CdS products (emission wavelength higher than $550 \mathrm{~nm}$ ) indicates the presence of impurity or defect states 


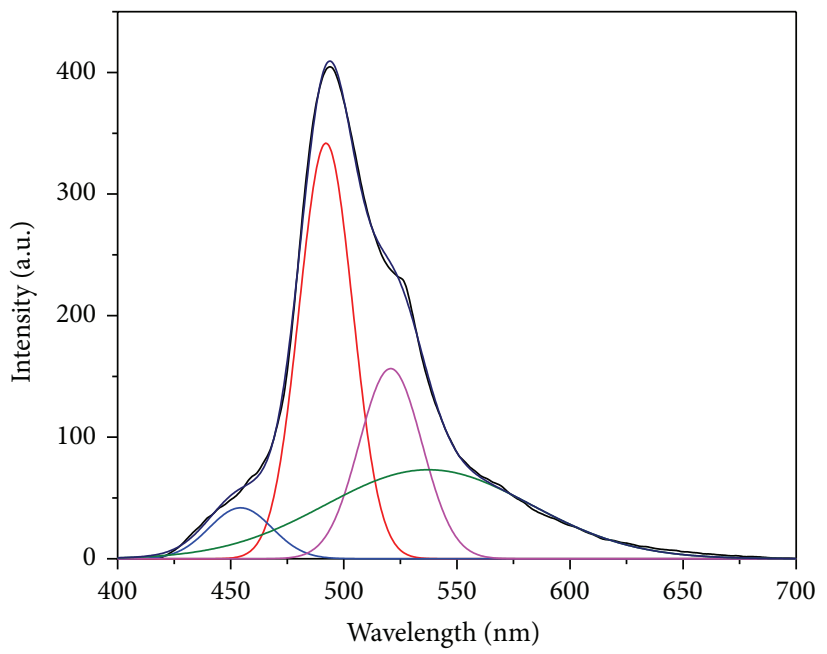

(a) $100^{\circ} \mathrm{C}, \mathrm{pH} 8.5$

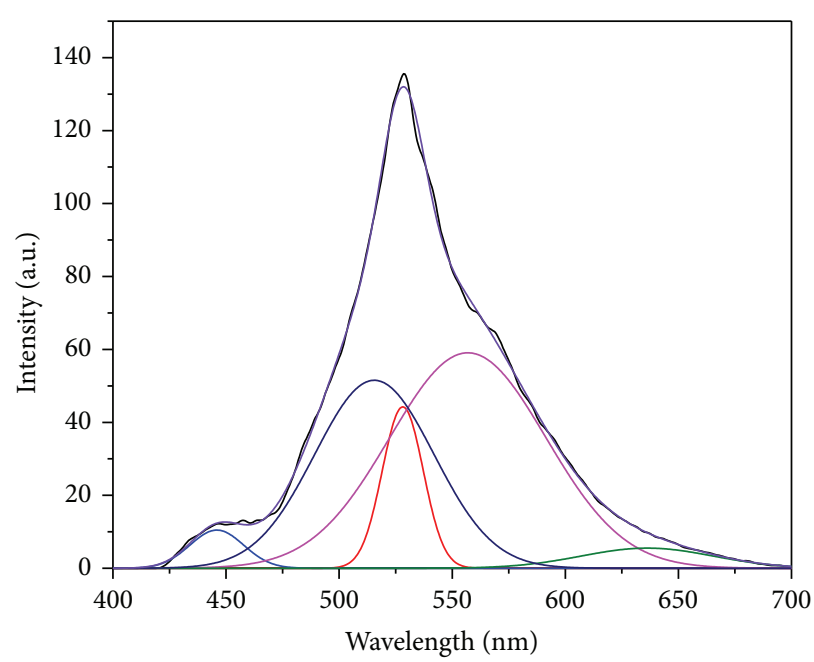

(c) $150^{\circ} \mathrm{C}, \mathrm{pH} 8.4$

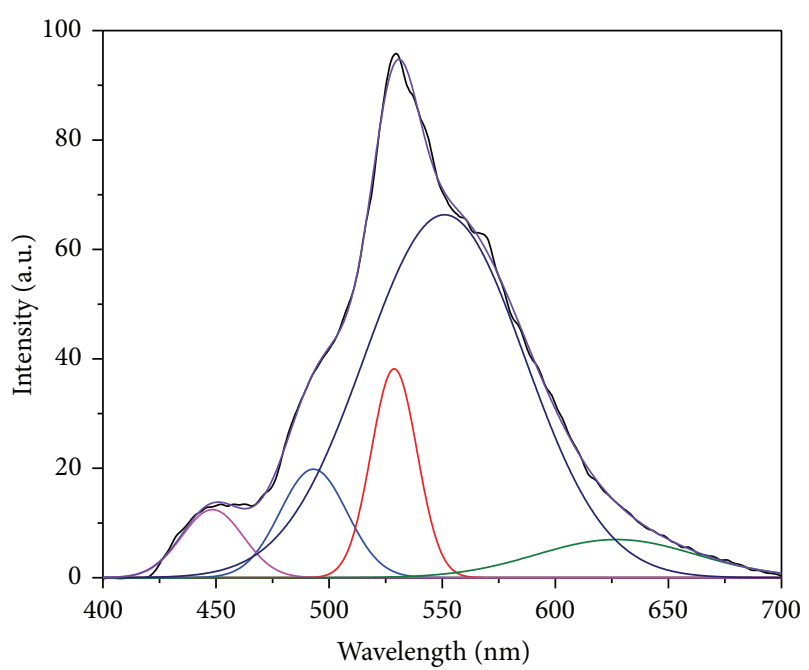

(b) $100^{\circ} \mathrm{C} \mathrm{pH} 11.3$

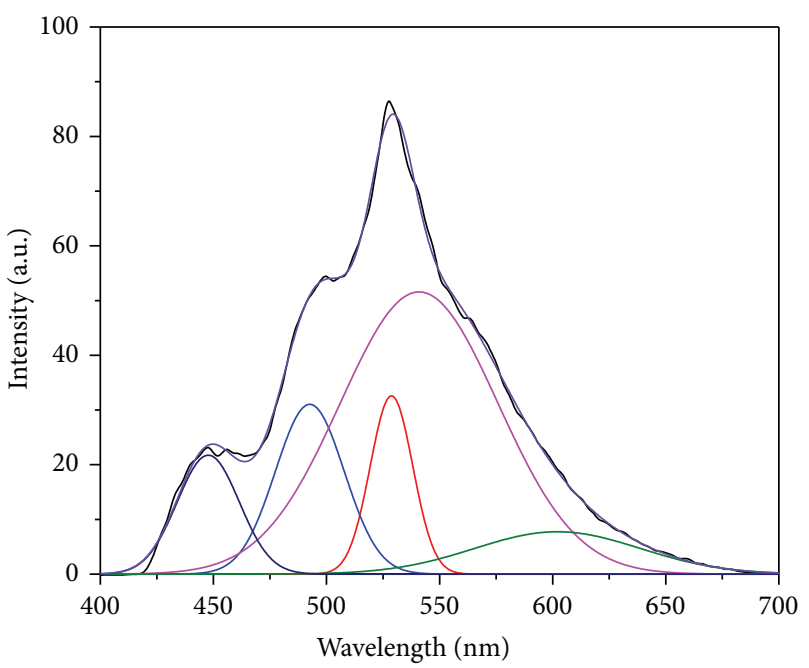

(d) $150^{\circ} \mathrm{C}, \mathrm{pH} 11.0$

Figure 6: Photoluminescence (PL) spectra of CdS nanoparticles synthesized at $100^{\circ} \mathrm{C}$ for 10 min from the solutions of (a) $\mathrm{pH} 8.5$ and (b) $\mathrm{pH}$ 11.3 and at $150^{\circ} \mathrm{C}$ for $10 \mathrm{~min}$ from the solutions of (c) $\mathrm{pH} 8.4$ and (d) $\mathrm{pH}$ 11.0.

in the compound. The impurity or defect states should result from the rapid crystal nucleation and growth by overheating (higher temperature of synthesis) or by accelerated hydrolysis of thiourea (higher solution $\mathrm{pH}$ ).

In all the obtained CdS products, it was observed that the PL spectra of green-yellow samples looked like that in Figure $6(\mathrm{a})$, and those of the orange ones were similar to those in Figures 6(b), 6(c), and 6(d). Combining the XRD and PL results, It is concluded that CdS products synthesized at low temperature from solutions of low $\mathrm{pH}$ contained small and photoluminescent nanoparticles with lower defect density. Higher reaction temperature and higher solution $\mathrm{pH}$ led to larger CdS crystals with higher density of surface or defect states. Resuming the results of the two sections, it is concluded that the size of CdS particles depends strongly on the solution $\mathrm{pH}$ values and the size of the CdS crystals, on both reaction temperature and solution $\mathrm{pH}$. Table 1 resumes the particle and crystal sizes of CdS products synthesized from solutions of different $\mathrm{pH}$ at 100 or $150^{\circ} \mathrm{C}$ for 10 or $30 \mathrm{~min}$.

3.3. Chemical Impurities at the Surface. As mentioned in the experimental section, the as-prepared CdS precipitates were rinsed with methanol and dried in air at room temperature. To prevent the loss of material, no further washing was carried on to the as-prepared CdS precipitates that could contain some impurities at the surface of the products. FTIR and TGA experiments were made on two CdS samples synthesized at the same temperature $\left(100^{\circ} \mathrm{C}\right.$ for $\left.10 \mathrm{~min}\right)$ but with different solution $\mathrm{pH}$ : one of $\mathrm{pH} 8.5$ and the other of $\mathrm{pH}$ 11.3. The FT-IR spectra of both samples suggested the presence of sodium citrate in the CdS products, and the difference was that the $\mathrm{pH} 8.5$ sample gave stronger intensity of the absorption peaks than the $\mathrm{pH} 11.3$ one. TGA curves of the two samples indicated that the lower $\mathrm{pH}$ sample 
TABle 1: Particle and crystal sizes of CdS products synthesized from solutions of different $\mathrm{pH}$ at 100 or $150^{\circ} \mathrm{C}$ for 10 or $30 \mathrm{~min}$.

\begin{tabular}{|c|c|c|c|c|c|c|c|c|}
\hline & $\begin{array}{l}\text { Particle size } \\
\text { (nm) }\end{array}$ & $\begin{array}{l}\text { Crystal size } \\
\text { (nm) }\end{array}$ & $\begin{array}{l}\text { White light } \\
\text { reflective color }\end{array}$ & $\begin{array}{l}\text { Emission band } \\
(\mathrm{nm})^{*}\end{array}$ & $\begin{array}{l}\text { Particle size } \\
\quad(\mathrm{nm})\end{array}$ & $\begin{array}{l}\text { Crystal size } \\
\text { (nm) }\end{array}$ & $\begin{array}{l}\text { White light } \\
\text { reflective color }\end{array}$ & $\begin{array}{c}\text { Emission } \\
\text { band }(\mathrm{nm})^{*}\end{array}$ \\
\hline & \multicolumn{8}{|c|}{ Time } \\
\hline & \multicolumn{5}{|c|}{$10 \mathrm{~min}$} & \multicolumn{2}{|c|}{$30 \mathrm{~min}$} & \\
\hline \multicolumn{9}{|c|}{$100^{\circ} \mathrm{C}$} \\
\hline $\mathrm{pH} 8.5$ & $117 \pm 18$ & 9.2 & Green-yellow & 492 & $126 \pm 21$ & 9.2 & Green-yellow & 492 \\
\hline $\mathrm{pH} 8.7$ & & & & & $102 \pm 18$ & 9.2 & Green-yellow & 492 \\
\hline pH 8.8 & & & & & $98 \pm 36$ & 9.2 & Green-yellow & 492 \\
\hline pH 10.8 & & & & & $52 \pm 15$ & 9.5 & Orange-yellow & 530 \\
\hline pH 11.2 & Chains & 10.0 & Orange-yellow & 530 & 40 & - & Orange-yellow & 530 \\
\hline \multicolumn{9}{|c|}{$150^{\circ} \mathrm{C}$} \\
\hline $\mathrm{pH} 8.4$ & $137 \pm 28$ & 10.4 & Orange-yellow & 530 & & & & \\
\hline $\mathrm{pH} 11$ & Clusters & 10.4 & Orange-yellow & 530 & & & & \\
\hline
\end{tabular}

* The maximum emission peak after the excitation by the $370 \mathrm{~nm}$ UV radiation.

TABLE 2: Photovoltaic parameters of ITO/CdS-f/CdS-n:P3HT/CP-Au solar cells with different synthesis conditions of CdS nanoparticles (CdS-n).

\begin{tabular}{|c|c|c|c|c|c|c|}
\hline Cell & $\begin{array}{l}\text { CdS-n preparation } \\
\text { conditions }\end{array}$ & $\begin{array}{l}\text { Particle/crystal } \\
\text { size }(\mathrm{nm})\end{array}$ & $J_{\mathrm{sc}}\left(\mathrm{mA} / \mathrm{cm}^{2}\right)$ & $V_{\text {oc }}(\mathrm{V})$ & $\mathrm{FF}$ & $\eta(\%)$ \\
\hline A & $100^{\circ} \mathrm{C} 10 \mathrm{~min} \mathrm{pH} 8.5$ & $117 / 9.2$ & 2.79 & 0.56 & 0.36 & 0.57 \\
\hline B & $100^{\circ} \mathrm{C} 30 \mathrm{~min} \mathrm{pH} 8.8$ & $98 / 9.2$ & 2.59 & 0.61 & 0.37 & 0.59 \\
\hline $\mathrm{C}$ & $100^{\circ} \mathrm{C} 30 \mathrm{~min} \mathrm{pH} 10.8$ & $51 / 9.5$ & 1.92 & 0.66 & 0.39 & 0.49 \\
\hline $\mathrm{D}$ & $150^{\circ} \mathrm{C} 10 \min \mathrm{pH} 8.5$ & $137 / 11.7$ & 1.40 & 0.73 & 0.36 & 0.37 \\
\hline $\mathrm{E}$ & $100^{\circ} \mathrm{C} 10 \mathrm{~min} \mathrm{pH} 11.3$ & Chain/9.9 & 1.2 & 0.32 & 0.40 & 0.16 \\
\hline $\mathrm{F}$ & $150^{\circ} \mathrm{C} 10 \mathrm{~min} \mathrm{pH} 11$ & Cluster/12.4 & 1.60 & 0.25 & 0.37 & 0.15 \\
\hline
\end{tabular}

showed a weight loss of $2.1 \mathrm{wt} \%$ at temperature range of 20 to $150^{\circ} \mathrm{C}$, which corresponded to the percentage of moisture or free water in the sample, and a weight loss of $3.3 \%$ at temperature range of 150 to $400^{\circ} \mathrm{C}$, corresponding to the percentage of sodium citrate or any other organic trace. In the case of higher $\mathrm{pH}$ sample, the loss of moisture was of $1.4 \mathrm{wt} \%$, and the organic compound loss at higher temperature range was about $2.0 \%$. As will be seen in the next section, this small difference on organic trace did not make differentiation among the photovoltaic performance of those cells.

Sodium citrate was soluble in water solution and served as the metal (cadmium) complex to release slowly cadmium ion during the formation of $\mathrm{CdS}$ molecules. The slow hydrolysis of TU in lower $\mathrm{pH}$ solution led to a lower product yield, and as a result, higher concentration of cadmium (citrate) trace could remain at the final CdS products. Comparing with the monodisperse CdS submicron particles obtained with PVP as antiagglomeration agent [14], the CdS products synthesized in this work contained less organic impurities $(<3.3 \%)$ during a short period of time (10 to $30 \mathrm{~min}$ ).

3.4. Photovoltaic Solar Cells. The photovoltaic performance of hybrid solar cells with some of the obtained CdS nanoparticles was analyzed and the curves of photocurrent density $(J)$ versus applied potential $(V)$ of six ITO/CdS-f/CdSn:P3HT/CP-Au solar cells with different types of CdS powders (CdS-n) were showed in Figure 7. Each $J-V$ curve was a representative of at least five $J-V$ curves of the "identical" cell samples prepared under the same experimental conditions. Table 2 enlists the photovoltaic parameters of the $J$ $V$ curves in Figure 7 and the synthesis conditions of the corresponding CdS powders. It is observed that cell samples $A$ and $B$ showed higher photocurrent density at short circuit $\left(J_{\mathrm{sc}}, 2.59\right.$ to $\left.2.79 \mathrm{~mA} / \mathrm{cm}^{2}\right)$, whereas samples $\mathrm{C}, \mathrm{D}, \mathrm{E}$, and $\mathrm{F}$ gave lower values of $J_{\text {sc }}\left(1.40\right.$ to $\left.1.92 \mathrm{~mA} / \mathrm{cm}^{2}\right)$. On the other hand, samples $\mathrm{A}, \mathrm{B}, \mathrm{C}$, and $\mathrm{D}$ gave higher photovoltage at open circuit $\left(V_{\text {oc }}, 0.56\right.$ to $\left.0.73 \mathrm{~V}\right)$, and samples $\mathrm{E}$ and $\mathrm{F}$ had low $V_{\text {oc }}(0.25$ to $0.32 \mathrm{~V})$.

It is observed that the green-yellow CdS products systematically originate higher $J_{\mathrm{sc}}$ in solar cells (cell samples $\mathrm{A}$ and $\mathrm{B}$ ). Orange-yellow CdS products, on the other hand, generated lower photocurrent density (cells C, D, E, and F). The difference could be from the different charge carrier mobility in the two types of CdS products. In a previous work [23] it is reported that CdS thin films deposited at lower temperature $\left(60^{\circ} \mathrm{C}\right)$ showed lower density of charge trapping centers than those deposited at higher one $\left(80^{\circ} \mathrm{C}\right)$. A lower density of charge trapping centers, in turn, leads to a larger charge mobility of the material and consequently larger charge carrier collection efficiency $\left(J_{\mathrm{sc}}\right)$ in the solar cells. Green-yellow CdS products were synthesized at lower temperature $\left(100^{\circ} \mathrm{C}\right)$ in solutions of lower $\mathrm{pH}$ values (8.58.8). It permitted a slower kinetics of $\mathrm{CdS}$ crystal nucleation 


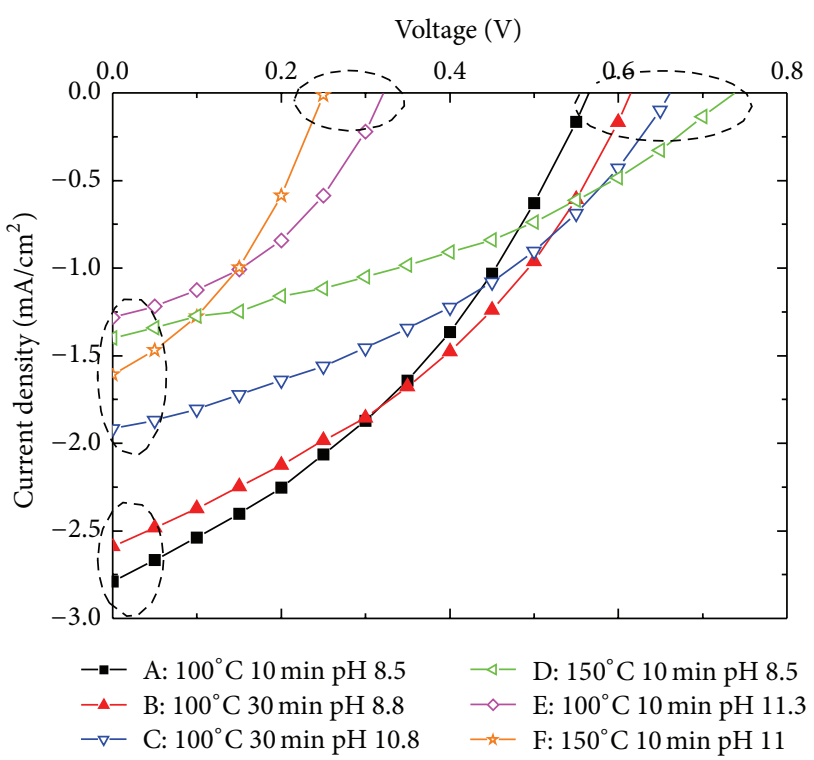

Figure 7: Photocurrent density (J) versus voltage curves of ITO/CdS-f/CdS-n:P3HT/CP-Au hybrid bulk solar cells with CdS nanoparticles (CdS-n) synthesized at different temperature during different interval of time for different $\mathrm{pH}$ values of the initial solutions.

and growth, and consequently the resulting CdS crystals contained lower density of bulk or surface defects. Orangeyellow CdS products, however, were synthesized at higher temperature $\left(150^{\circ} \mathrm{C}\right)$ or in higher $\mathrm{pH}$ solutions (10.8-11.3). The accelerated $\mathrm{CdS}$ crystal nucleation and growth led to larger imperfection density inside the orange-yellow CdS samples, as suggested by their PL spectra (Figures 6(b), 6(c), and 6(d)). As a result, smaller $J_{\text {sc }}$ of the corresponding solar cells had been obtained.

The photovoltage $\left(V_{\mathrm{oc}}\right)$ of the hybrid cells, on the other hand, seems to be related to the good dispersion of monodisperse spherical CdS particles in P3HT solution. It is observed that relatively good $V_{\text {oc }}$ was found in all the cells with spherical particles of CdS. Lower $V_{\text {oc }}$ values were observed in the solar cells that contained CdS products with morphology of large clusters or chains (Figures 3(c) and 3(e), cell samples $\mathrm{E}$ and $\mathrm{F}$ in Figure 7).

\section{Conclusions}

Monodisperse spherical CdS nanoparticles from 51 to $140 \mathrm{~nm}$ can be obtained by microwave assisted heating from solutions that contained cadmium salt, sodium citrate, $\mathrm{pH}$ adjuster $(\mathrm{KOH})$, and thiourea. At the same reaction temperature, lower $\mathrm{pH}$ solutions (8.4 to 8.8) promoted formation of larger spherical CdS particles, whereas higher $\mathrm{pH}$ solutions took longer time to form smaller $\mathrm{CdS}$ spheres. The combination of slow kinetics of reaction at lower $\mathrm{pH}$ and homogeneous microwave heating made the formation of monodisperse spherical CdS nanoparticles at low reaction temperature in a short period of time possible. High reaction temperature as well as high solution $\mathrm{pH}$ accelerated the kinetics of CdS reaction, leading to the CdS crystals with larger defect density. Monodisperse spherical CdS nanoparticles could be well dispersed in poly(3-hexylthiophene) (P3HT) solutions and gave a good photovoltage $(0.56$ to $0.73 \mathrm{~V})$. Those spherical $\mathrm{CdS}$ nanoparticles with less density of defect states gave a relatively good photocurrent density ( 2.59 to $\left.2.79 \mathrm{~mA} / \mathrm{cm}^{2}\right)$. It is demonstrated that microwave chemistry can accelerate the reaction kinetics and produce homogeneous heating, which is an efficient option to prepare monodisperse semiconductor nanoparticles for solar cell applications.

\section{Conflict of Interests}

The authors declare that there is no conflict of interests regarding the publication of this paper.

\section{Acknowledgments}

The authors thank Rogelio Morán for SEM images, María Luisa Ramón for XRD measurements, and Patricia Altuzar for FT-IR and TGA experiments. Special thanks are due to Dr. P. J. Sebastian for the microwave oven facility. Financial supports from CONACyT CB/2012 (no. 178023), PAPIIT-UNAM (IN100613), and CONACyT SENER-CeMIE-Sol (2013-02, no. 27) are acknowledged. Claudia Martínez-Alonso and Carlos A. Rodríguez-Castañeda thank CONACyT for the scholarships.

\section{References}

[1] J. Weickert, R. B. Dunbar, H. C. Hesse, W. Wiedemann, and L. Schmidt-Mende, "Nanostructured organic and hybrid solar cells," Advanced Materials, vol. 23, no. 16, pp. 1810-1828, 2011.

[2] M. Wright and A. Uddin, "Organic-inorganic hybrid solar cells: a comparative review," Solar Energy Materials \& Solar Cells, vol. 107, pp. 87-111, 2012.

[3] B. R. Saunders, "Hybrid polymer/nanoparticle solar cells: preparation, principles and challenges," Journal of Colloid and Interface Science, vol. 369, no. 1, pp. 1-15, 2012.

[4] T.-T. Xuan, J.-Q. Liu, H.-L. Li et al., "Microwave synthesis of high luminescent aqueous $\mathrm{CdSe} / \mathrm{CdS} / \mathrm{ZnS}$ quantum dots for crystalline silicon solar cells with enhanced photovoltaic performance," RSC Advances, vol. 5, no. 10, pp. 7673-7678, 2015.

[5] S. Wageh, A. A. Al-Ghamdi, M. Soylu, Y. Al-Turki, N. AlSenany, and F. Yakuphanoglu, "CdS quantum dots and dye cosensitized nanorods $\mathrm{TiO}_{2}$ solar cell," Journal of Nanoelectronics and Optoelectronics, vol. 9, no. 5, pp. 662-665, 2014.

[6] M. J. Speirs, D. M. Balazs, H.-H. Fang et al., "Origin of the increased open circuit voltage in PbS-CdS core-shell quantum dot solar cells," Journal of Materials Chemistry A, vol. 3, no. 4, pp. 1450-1457, 2015.

[7] S. Ren, L.-Y. Chang, S.-K. Lim et al., "Inorganic-organic hybrid solar cell: bridging quantum dots to conjugated polymer nanowires," Nano Letters, vol. 11, no. 9, pp. 3998-4002, 2011.

[8] Y. Zhang and A. Clapp, "Overview of stabilizing ligands for biocompatible quantum dot nanocrystals," Sensors, vol. 11, no. 12, pp. 11036-11055, 2011. 
[9] C. Martínez-Alonso, H. J. Cortina-Marrero, C. Selene CoriaMonroy, M. C. Arenas, M. E. Nicho, and H. Hu, "Solution synthesized CdS nanoparticles for hybrid solar cell applications," Journal of Materials Science: Materials in Electronics, 2014.

[10] E. Matijević and D. M. Wilhelmy, "Preparation and properties of monodispersed spherical colloidal particles of cadmium sulfide," Journal of Colloid And Interface Science, vol. 86, no. 2, pp. 476-484, 1982.

[11] K.-S. Chou and S.-R. Horng, "Study on the growth of monodispersed cadmium sulfide particles," Chemical Engineering Communications, vol. 79, no. 1, pp. 85-94, 1989.

[12] S. Libert, V. Gorshkov, V. Privman, D. Goia, and E. Matijević, "Formation of monodispersed cadmium sulfide particles by aggregation of nanosize precursors," Advances in Colloid and Interface Science, vol. 100-102, pp. 169-183, 2003.

[13] J. A. Gerbec, D. Magana, A. Washington, and G. F. Strouse, "Microwave-enhanced reaction rates for nanoparticle synthesis," Journal of the American Chemical Society, vol. 127, no. 45, pp. 15791-15800, 2005.

[14] X.-H. Li, J.-X. Li, G.-D. Li, D.-P. Liu, and J.-S. Chen, "Controlled synthesis, growth mechanism, and properties of monodisperse CdS colloidal spheres," Chemistry, vol. 13, no. 31, pp. 8754-8761, 2007.

[15] C. Martínez-Alonso, C. A. Rodríguez-Castañeda, P. MorenoRomero, C. S. Coria-Monroy, and H. Hu, "Cadmium sulfide nanoparticles synthesized by microwave heating for hybrid solar cell applications," International Journal of Photoenergy, vol. 2014, Article ID 453747, 11 pages, 2014.

[16] M. C. Arenas, N. Mendoza, H. Cortina, M. E. Nicho, and H. $\mathrm{Hu}$, "Influence of poly3-octylthiophene (P3OT) film thickness and preparation method on photovoltaic performance of hybrid ITO/CdS/P3OT/Au solar cells," Solar Energy Materials \& Solar Cells, vol. 94, no. 1, pp. 29-33, 2010.

[17] H. J. Cortina-Marrero, P. K. Nair, and H. Hu, "Conductive carbon paint as an anode buffer layer in inverted CdS/Poly(3hexylthiophene) solar cells," Solar Energy, vol. 98, part C, pp. 196-202, 2013.

[18] P. C. Rieke and S. B. Bentjen, "Deposition of cadmium sulfide films by decomposition of thiourea in basic solutions," Chemistry of Materials, vol. 5, no. 1, pp. 43-53, 1993.

[19] R. Ortega-Borges and D. Lincot, "Mechanism of chemical bath deposition of cadmium sulfide thin films in the ammoniathiourea system: in situ kinetic study and modelization," Journal of the Electrochemical Society, vol. 140, no. 12, pp. 3464-3473, 1993.

[20] R. G. Chaudhuri and S. Paria, "Core/shell nanoparticles: classes, properties, synthesis mechanisms, characterization, and applications," Chemical Reviews, vol. 112, no. 4, pp. 2373-2433, 2012.

[21] S. R. Dhage, H. A. Colorado, and H. T. Hahn, "Photoluminescence properties of thermally stable highly crystalline CdS nanoparticles," Materials Research, vol. 16, no. 2, pp. 504-507, 2013.

[22] P. A. Kurian, C. Vijayan, K. Sathiyamoorthy, C. S. Suchand Sandeep, and R. Philip, "Excitonic transitions and off-resonant optical limiting in CdS quantum dots stabilized in a synthetic glue matrix," Nanoscale Research Letters, vol. 2, no. 11, pp. 561568, 2007.

[23] H. Cortina, E. Pineda, J. Campos, M. E. Nicho, and H. Hu, "Photogenerated charge carrier recombination processes in CdS/P3OT solar cells: effect of structural and optoelectronic properties of CdS films," European Physical Journal: Applied Physics, vol. 55, no. 3, Article ID 30901, 8 pages, 2011. 

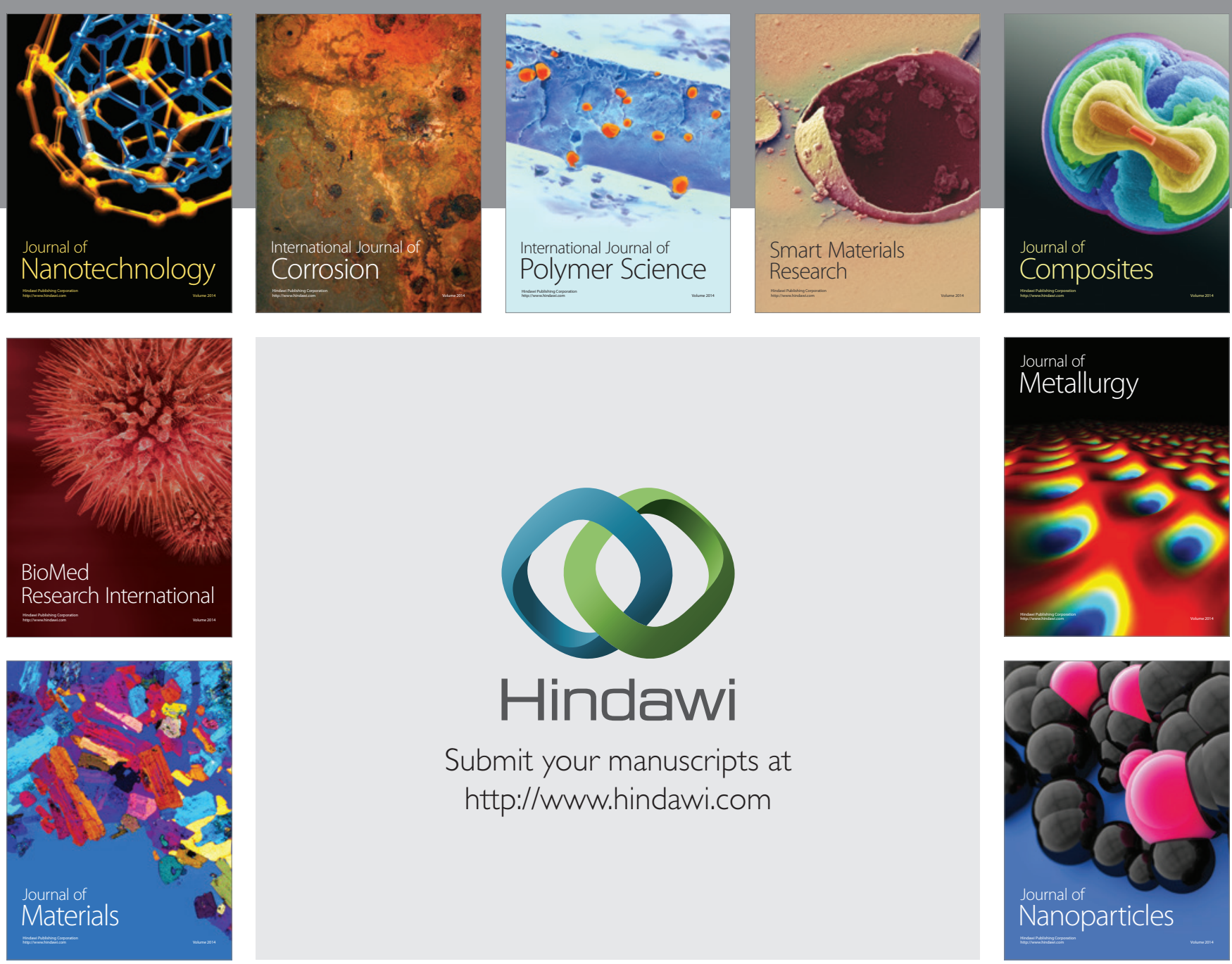

Submit your manuscripts at http://www.hindawi.com
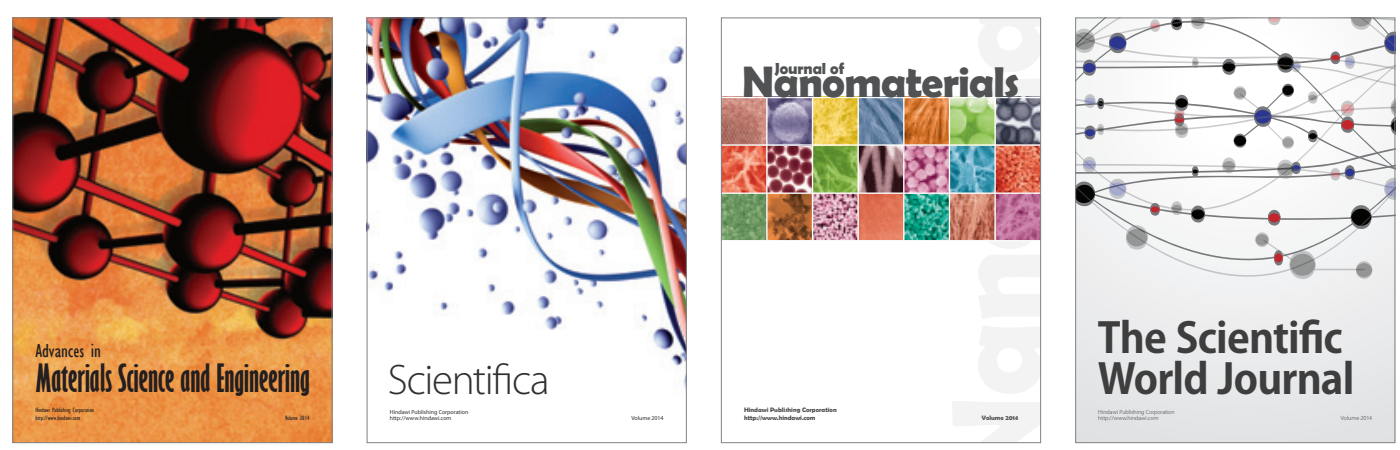

\section{The Scientific World Journal}
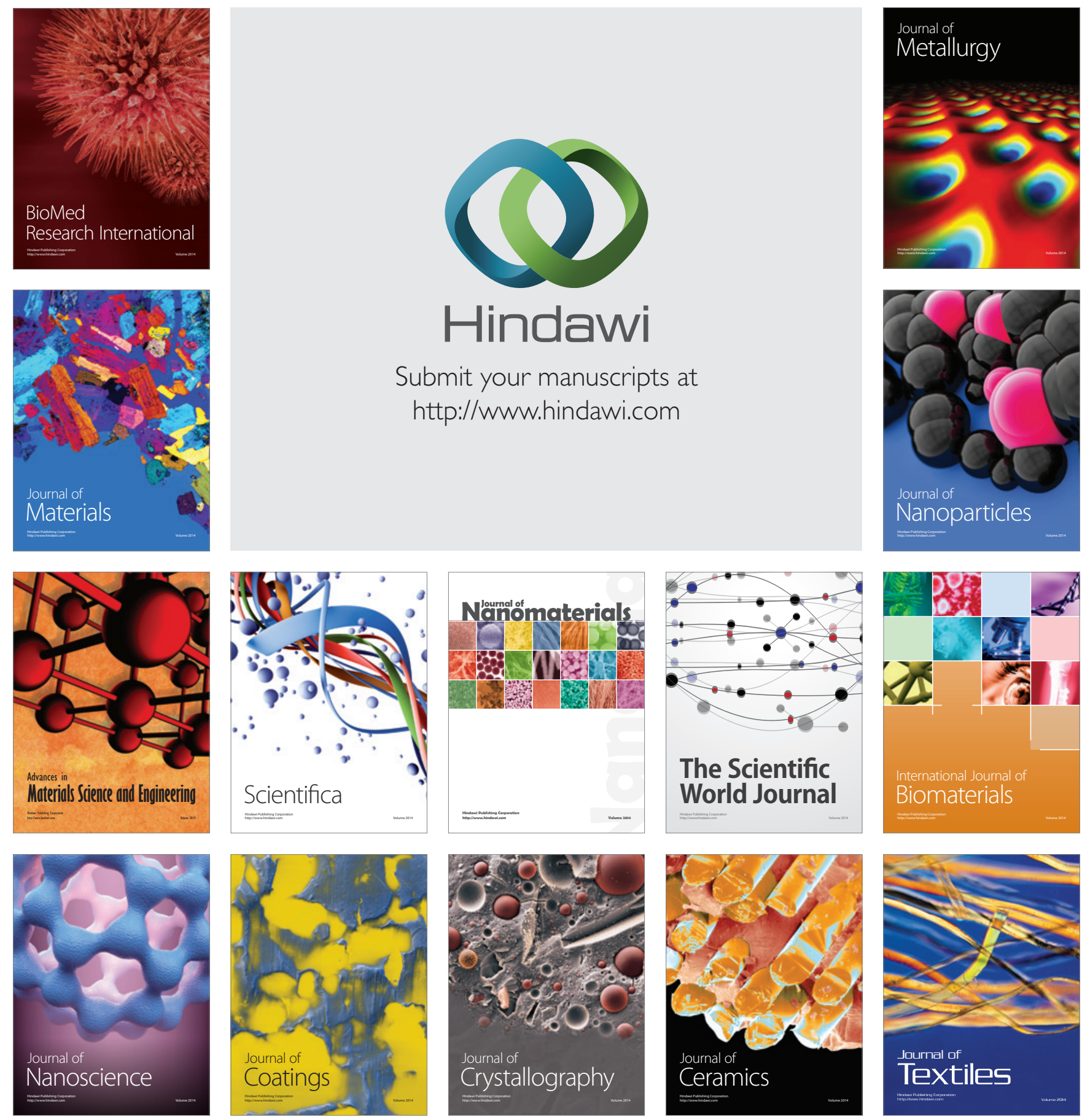